\title{
Ex situ method and Salix spp. to treat polluted soil with hydrocarbon
}

\author{
Sydney Sabedot' \\ Sérgio Augusto de Loreto Bordignon" \\ Ana Cristina Borda da Cunha"II
}

\section{Abstract}

This study shows the practices for managing ex situ soil with a simulation in which a residue derived from hydrocarbons with a sandy-silty soil was mixed, and two Salix spp. varieties were planted in the mixture. The experiment took place in a greenhouse and controls on plants and soil occurred during 36 months. The experiment aimed at two objectives, the first of which was to evaluate the development and resistance of the plants in the contaminated soil, comparing them with their planting in sandy-silty soil without the residue, and the second was to evaluate the performance of plants as phytoremediators of the residue. This study deals with the first goal. The success in sprouting and in development of the plants was verified in both types of soils. The diameter and height of the stems and the dimensions of the leaves were the measured parameters. Statistical analysis of the data indicated that Salix triandra species developed better. The joint result for both the above mentioned objectives indicated that the ex situ method for treating soils contaminated with hydrocarbons and the planting of two species of willow were effective and can be reproduced in similar conditions to those described in this study.

Keywords: Soil mitigation; Phytoremediation; Ex situ method 


\section{Introduction}

This paper presents a research method for soil management contaminated by hydrocarbon derivatives, with the application of the ex situ technique and the use of two species of willow plants in a greenhouse, to assess the potential of phytoremediation of the willows in soil samples contaminated with a substance consisting of a ship fuel called Marine Fuel Oil 380 (IFO 380). The experiment was performed by the simulation of contamination of the referred substance in a soil. In order to mitigate the environmental impact, a method for decontaminating of this soil with the use of Salix spp (Salicaceae) kind of plants was applied.

Previous studies of Belgian researchers showed the effectiveness of Salix spp. species in many experiments with soils contaminated with heavy metals and other substances in Belgium and other countries (DICKINSON et al., 1994; ERICKSSON; LEDIN, 1999; GOOR et al., 2001; MERTENS et al., 2001; VERVAEKE et al., 2001; KLANG-WESTIN; PERTTU, 2002; VANDECASTEELE et al., 2002; MEERS et al., 2003; VERVAEKE et al., 2003). The positive results of these studies were encouraging for the group to reproduce a similar experiment in southern Brazil.

As the cited studies with Salix spp. occurred in regions of low temperatures, where the plants have vigorous growth, this research outlined apparent challenges because the region chosen for the experiment has higher temperatures. At the site chosen for the implementation of the project, a rural property of Unilasalle, in Canoas, in the State of Rio Grande do Sul, the climate is subtropical. Furthermore, the experiments cited in the studies were developed in situ, with direct planting in contaminated or polluted soils.

When the research was planned, there were no scientific sources found about similar experiments to report on ex situ phytoremediation, the use of the Salix spp. species and greenhouse. In this context, the researchers identified the opportunity to carry out original work.

Thus, this paper describes methodological procedures for soil preparation, planting and care during the growth for both species of Salix and sampling procedures for analyses. It is not about methods and results about the potential of the plants as phytoremediators, or as to the final quality of the treated soil in the experiment, an approach already held in Cunha et al. (2012), but presents data on statistical evaluations about the plant growth.

Phytoremediation is a technique that appeared in 1991 as a low cost alternative to polluted soil rehabilitation or contaminated with heavy metals, inorganic compounds, radioactive chemical elements and hydrocarbons derived from petroleum, among others (CUNNINGHAM et al., 1996). It consists of an in situ treatment mediated by plant species to extract, contain, immobilize or degrade contaminants from water and soil, enabling the return of the functionality and stability of the ecosystem. The researches in this area seek to understand the interaction of the plant with the contaminant (MCCUTCHEON; SCHNOOR, 2003; AL-TAISAN, 2009; MUDGAL et al.,
2010; BHARGAVA et al., 2012.). An alternative method is the removal of soil for its rehabilitation by the ex situ chemical treatment, cited by Mulligan et al. (2001) as an effective technique in small areas, but more harmful to the environment and with higher costs.

The plant known as willow is a product of plant species of the Salix gender, of the Salicaceae family that has several applications, such as amarrillos in agriculture (especially vineyards), baskets for work in agricultural activities, crafts and furniture manufacturing. It is also used in landscaping, bioengineering and phytoremediation treatments. There are about 300 known species of trees and shrubs of Salix scattered in different continents, associated with wet soils of cold and temperate climates. However, there are several species of Salix that fit in dry areas. The shrubby forms are traditionally used in crafts and basketry, which are called willow. The Salix viminalis L., Salix purpurea L., Salix cinerea L., Salix caprea L., Salix triandra L., Salix alba L. subsp. vitellina and Salix fragilis L. varieties stand out. In Brazil, the willow plant is grown since the nineteenth century, introduced by European immigrants, and is an important source of income for thousands of small farmers in the Planalto Serrano Catarinense region, in the State of Santa Catarina. The plants include a large number of genotypes, including species, natural clones and hybrids. In this region, the material is derived exclusively from natural Salix x rubens Schrank hybrid. Clones of Salix x rubens species originate vigorous plants and of good adaptation to edaphoclimatic conditions in the Planalto Serrano Catarinense region. The research institutions Empresa de Pesquisa Agropecuária e Extensão Rural de Santa Catarina (EPAGRI) and Embrapa Recursos Genéticos e Biotecnologia (CENARGEN) started in the region to introduce new species of Salix originating from Germany, France, Chile and Argentina to meet quality requirements of rods for making fine handmade pieces, which are not found in the Salix x rubens species (MEIKLE, 1984; MOURA, 2001; CARPANEZZI et al., 2002; CASA et al., 2007).

The aim of this paper is to present a method of research for the decontamination of a soil managed ex situ, contaminated with a ship fuel, by the planting of two varieties of plants of the Salix spp species, in a greenhouse, and potential assessment of phytoremediation of the plants in the mitigating of a simulated environmental impact.

\section{Material and Methods}

\section{Residue}

The residue is a mixture of soil and IFO 380 substance. The substance corresponds to a mixture of fuel oil and diesel used as ship fuel (VERMEIRE, 2012). It was not possible to determine the individual masses of the components of the residue, because the material was composed of a mixture of grains of pebbles, sand, silt and clay impregnated with the substance heterogeneously and of difficult separation. 


\section{Soil}

The soil in the planting was collected in situ in a rural area of Canoas ( $29^{\circ} 52^{\prime} 34^{\prime \prime} \mathrm{S}$ and $51^{\circ} 08^{\prime} 05^{\prime}$ ' W), which served as a source of soil for various activities and works of the municipality. About $18 \mathrm{~m} 3$ of soil were extracted from the area and transported by a bucket truck to the site of the experiment.

Physical, agronomic and chemical analyzes were performed on soil samples, and chemical analysis were performed on residue samples. The results were important to evaluate the fertility of the soil, the chemical components present in the soil and in the residue and the proper proportion for soil mixture and residue, so as to allow the development of plants in boxes filled with the mixed soil type.

Physical analyzes were performed on soil samples in the Soil Laboratory of the Unilasalle to determine the grain size distribution of the soil, using vibrating sieving and seven grain size sieves of different meshes. Agronomic analyzes were performed in the Soils Laboratory of the UFRGS School of Agronomy. Chemical soil analyzes were performed in the Chemical Laboratory of the Federal University of Santa Maria (UFSM). The chemical residue analyzes were performed in the Environmental Analytical Chemistry Laboratory and Oil Chemistry of the UFRGS (BTEX; PAHs; pH), in the Laborquímica Laboratory (mineral oils and greases; oils and greases from vegetables and animals) and in the Chemical Laboratory of the UFSM (23 chemical elements).

The mass of soil distribution by particle sizes indicated that this is silty sand, according to the textural diagram employed in soil surveys in Brazil (LEMOS; SANTOS, 1982).

\section{Willow Plants}

The research was designed to evaluate both the Salix $\mathrm{x}$ rubens and Salix triandra species as phytoremediators plants. The Salix $x$ rubens is a species widely used for the manufacture of furniture, handicrafts and as support material for planting vines in southern Brazil. The Salix triandra is not a species used in the region and its choice for the research was due to its good growth performance, observed in experiments conducted by willow producers in the municipality of Bom Retiro do Sul, in State of Santa Catarina.

\section{Experimental Model}

The project lasted 36 months, starting in October (year1) and completed in September (year3), respectively, with the planting of willows seedlings and the collection of the last samples of soils and plants for analyses. The experiments were performed in triplicate and in the $2^{2}$ factorial model (two soil types and two varieties of willow), resulting in 12 planting boxes. For search controls, two more boxes were filled, one with the soil and the other with the soil and residue mixing, and that both remained without plants, but that they received the same mode of irrigation than the others. Figure 1 illustrates the location of each box in the experiment with the planted willow species and soil types.

\section{Figure 1 - Disposal of the boxes in the experiment}

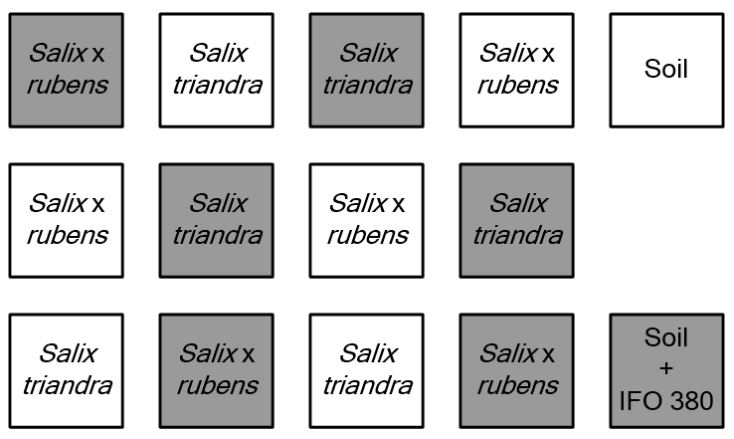

\section{Preparation of the Soils}

Initially, the substances calcium carbonate and magnesium carbonate and of N, P and $\mathrm{K}$ were added to soil for $\mathrm{pH}$ adjustment and addition of inorganic nutrients for the soil. The mixture of soil and residue occurred in the proportion, respectively, $80 \%$ and $20 \%$, which was placed in seven boxes.

In Figure 1, the white squares represent boxes that were filled with the soil mix, carbonates and nutrients $\mathrm{N}, \mathrm{P}$ and $\mathrm{K}$. The masses were previously determined and homogenized in batch operations in mixer equipment similar to that used in the civil construction, in three minutes time. The resulting material was added to the boxes and the operations were repeated as many times as necessary for the individual filling of the seven boxes. The gray squares represent boxes that were filled with the mixture of soil and residue, in addition to the N, P and $\mathrm{K}$ and carbonates components. The homogenization of the materials and the filling of the remaining seven boxes were repeated in the same equipment and the before mentioned manner.

\section{Seedlings of Willow and Planting}

The seedlings of the two species of willow were provided by the Zandonai, Journet and Thomas Ltda. Company, having as matrix the plants produced in the company's ownership, in Bom Retiro do Sul, Brazil. The seedlings amounted to willow sticks segments about 30 $\mathrm{cm}$ long (Figure 2).

A technician of the quoted company did the planting in October/year1. There were placed 36 seedlings of the same species in each box, homogeneously distributed and buried about $10 \mathrm{~cm}$ in the same procedure in the two soil types (Figure 3). According to the technician, the month of planting was considered late, for in the State of Santa Catarina seedlings are usually planted in February and March. The technician suggested placing the polyethylene film only on the roof of the greenhouse structure. The film was not placed on the sides of the 
structure.

Figure 2 - Sticks used as seedlings

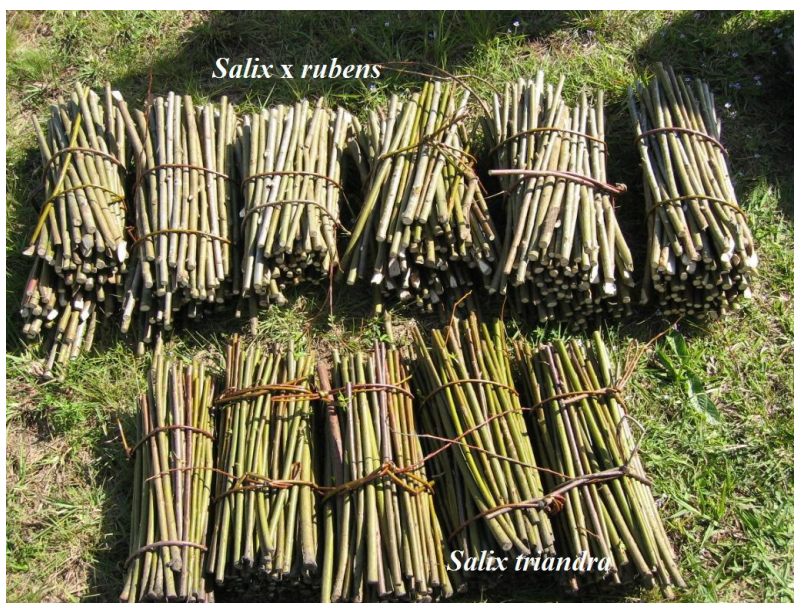

Figure 3 - Box with newly planted willow seedlings

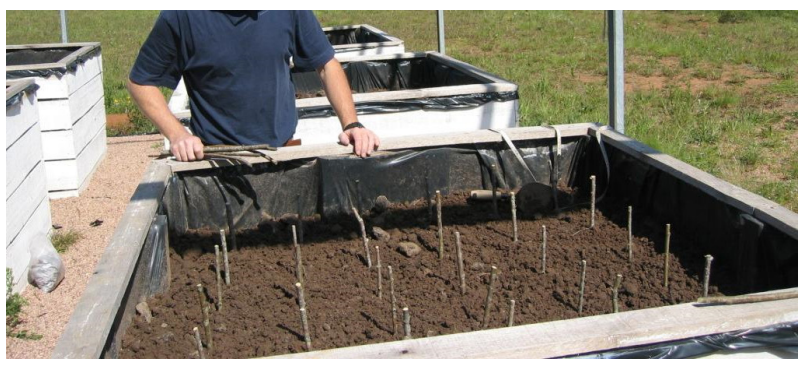

\section{Procedures for the Development of Plants}

Three factors were important for the budding and the healthy growth of willows in a plantation: clay soil, well-structured e with humidity. However, the biggest challenge was related to the climate issue, especially during the first year of the seedling development, considering that they were planted late and in a different climate of the Planalto Serrano Catarinense, where the seedlings came from. In this context, humidity control would only fit. Irrigation was performed three times per week, in the early mornings or late afternoons during 30 minutes, in the spring, autumn, and winter, and every day in the summer, as the soil is of little clay and the weather conditions are hot and of low humidity.

As for insects, there were infestations of aphids and ants. As it was not fit for the use of insecticides for ants, it was opted for the placement of baits to external boxes, which solved the problem partially. For aphids, the infestation was controlled daily spraying a $30 \%$ coconut soap solution. The incidence of insects did not harm the development of plants.

In addition, fungal infestations occurred. Branches, green leaves and necrotic leaves were subjected to phytosanitary diagnostics in the Phytosanitary and Consultancy Diagnostic Laboratory. The analysis accounted for examination under a stereoscope and optical microscope of the structures and their comparison with those illustrated in specific bibliography. For the control of fungi, periodic thinning rods were made, around 50\% of the plants in each box so that the others could have more space in the development of sticks and leaf mass. In addition, the humidity control was more rigorous.

Plant growth was evaluated by measurements of the stem diameter, the plant height and the length and width of the leaves. The control of the stem was made at its base and at the apex with the use of a caliper. The diameter of the base was measured at a point of two centimeters above the ground, and the apex diameter was measured at a point of three knots below the apical bud. Plant height was measured from the ground to the apex and with the use of a measuring tape. The length and width of the leaves were measured with a ruler. For each box 10 plants were measured at random, and from each plant were taken 20 leaves were taken off.

\section{Soil Samples and Willows Collection}

Soil samples from all the boxes were collected and analyzed twice: one before planting the seedlings, and another 36 months after planting, in the completion of the experiment. In the first collection, several aliquots were removed from the boxes during their fillings. Thus, each box had a composite sample, which has been homogenized and successively reduced to form appropriate aliquots for analyses. For the last collection, the boxes were removed and a number of soil samples were collected in each one, from the top of the box to the depth in which the roots of plants were developed, forming also a composite sample that was homogenized and reduced which generated rates for analysis.

The plant sample collections occurred 18 and 36 months after planting. In each sample leaves, stems and roots were collected. The leaves were collected from all plants in each box. Stems and roots were collected from three plants chosen at random in each box. Collection procedures were performed, preparation and packaging of plant samples according to specific instructions by the laboratories that analyzed them.

\section{Removal and Final Discard of Materials}

Finishing the experiment, the dismantling of the structure and the removal of the materials used in it were proceeded, because the site should return to the preconditions of the research. The way how the experiment was structured facilitated the removal of all materials (used sample rates or not in the analysis, soil, soil mixed with residue, unused residue remaining plants, plastic containers used, wooden boards and black plastic). The materials that had contact with the residue were removed by Colix-RGS Company that provided all environmental documentation, stowed materials, transported and allocated them to the pro-environment industrial landfill in compliance and conformity with the requirements of environmental legislation. The materials that had no contact with the residue had different destination. 


\section{Results and Discussion}

\section{Physical and Chemical Analyses}

The mass of soil distribution by particle sizes indicated that this is silty sand, according to the textural diagram employed in soil surveys in Brazil (LEMOS; SANTOS, 1982). Under this classification, the soil had different texture than the clay soils of the region in which the willows are planted in the State of Santa Catarina.
The results of the agronomic soil and chemical analysis of the soil and residue are shown in Tables 1 and 2, respectively.

The results of the Table 1 indicated a soil with low clay $(16 \%)$, low $\mathrm{pH}$ value (4.4), unsuitable for willow planting, and need correction for some inorganic nutrients for normal plant growth. The amount of clay was not altered, but results were important to allow the correction of $\mathrm{pH}$ and inorganic nutrients of the soil with calcium carbonate and magnesium carbonate and $\mathrm{N}, \mathrm{P}$ and $\mathrm{K}$.

Table 1 - Agronomic analysis results in soil sample used in the experiment

\begin{tabular}{|c|c|c|c|c|c|c|c|c|c|c|}
\hline $\begin{array}{l}\text { Clay } \\
\text { (\%) }\end{array}$ & $\mathrm{pH}$ & $\begin{array}{l}\text { Index } \\
\text { SMP }\end{array}$ & $\begin{array}{l}\text { P } \\
(\mathrm{mg} / \\
\left.\mathrm{dm}^{3}\right)\end{array}$ & $\begin{array}{l}\mathrm{K}(\mathrm{mg} / \\
\left.\mathrm{dm}^{3}\right)\end{array}$ & $\begin{array}{l}\text { OM } \\
(\%)\end{array}$ & $\begin{array}{l}\text { Alexcl } \\
\text { (cmolc }\end{array}$ & $\begin{array}{l}7^{*} \\
\left.c / \mathrm{dm}^{3}\right)\end{array}$ & & $\begin{array}{l}\text { xch* } \\
\text { olc/dm }{ }^{3} \text { ) }\end{array}$ & $\begin{array}{l}\text { Mgexch* } \\
\left(\mathrm{cmolc} / \mathrm{dm}^{3}\right)\end{array}$ \\
\hline 16.0 & 4.4 & 4.9 & 3.2 & 33.0 & 2.2 & & 2.3 & & 0.9 & 0.3 \\
\hline \multirow{2}{*}{\multicolumn{2}{|c|}{$\begin{array}{c}\mathrm{Al}+\mathrm{H}\left(\mathrm{cmol}_{\mathrm{c}} /\right. \\
\left.\mathrm{dm}^{3}\right)\end{array}$}} & \multirow{2}{*}{\multicolumn{2}{|c|}{$\begin{array}{l}\mathrm{CEC}^{* *} \\
\left(\mathrm{cmol}_{\mathrm{c}} /\right. \\
\left.\mathrm{dm}^{3}\right)^{\prime}\end{array}$}} & \multicolumn{2}{|c|}{ \% Sat ${ }^{* * *}$ CEC } & \multicolumn{5}{|c|}{ RATIO } \\
\hline & & & & BASES & Al & & $\mathrm{Ca} / \mathrm{Mg}$ & & $\mathrm{Ca} / \mathrm{K}$ & $\mathrm{Mg} / \mathrm{K}$ \\
\hline \multirow{2}{*}{\multicolumn{2}{|c|}{$\frac{15.4}{\mathrm{~S}\left(\mathrm{mg} / \mathrm{dm}^{3}\right)}$}} & \multicolumn{2}{|c|}{16.8} & 8.0 & 63.0 & & 2.0 & & 11.0 & 3.5 \\
\hline & & $\begin{array}{r}\mathrm{Zn}(\mathrm{r} \\
\mathrm{dm}\end{array}$ & & $\mathrm{Cu}$ (mg/dr & \multicolumn{2}{|c|}{$\mathrm{B}\left(\mathrm{mg} / \mathrm{dm}^{3}\right)$} & \multicolumn{2}{|c|}{$\begin{array}{c}\mathrm{Mn}(\mathrm{mg} / \\
\left.\mathrm{dm}^{3}\right)\end{array}$} & $\mathrm{Fe}\left(\mathrm{mg} / \mathrm{dm}^{3}\right)$ & $\mathrm{Na}\left(\mathrm{mg} / \mathrm{dm}^{3}\right)$ \\
\hline \multicolumn{2}{|c|}{7.8} & & & 1.5 & \multicolumn{2}{|c|}{0.4} & \multicolumn{2}{|c|}{36.0} & 2.1 & 14.0 \\
\hline
\end{tabular}

* Exchangeable ** Cation Exchange Capacity ${ }^{* * *}$ Saturation

Table 2 - Chemical analyzes of samples of residue and soil, separately

\begin{tabular}{|c|c|c|c|c|c|c|}
\hline Analyte & $\begin{array}{l}\text { Residue ( } \mu \mathrm{g} \\
\left.\mathrm{g}^{-1}\right)\end{array}$ & Analyte & $\begin{array}{l}\text { Residue ( } \mu \mathrm{g} \\
\left.\mathrm{g}^{-1}\right)\end{array}$ & Soil $\left(\mu g^{-1}\right)$ & Analyte & Residue (\%) \\
\hline Benzene & ND & C & $1.40^{*}$ & $0.85^{*}$ & \multirow{4}{*}{$\begin{array}{c}\text { Oils and greases } \\
\text { (animal/vegetable) } \\
\text { Oils and greases } \\
\text { (mineral) }\end{array}$} & \multirow{4}{*}{$\begin{array}{l}1.07 \\
5.01\end{array}$} \\
\hline Toluene & 0.000545 & $\mathrm{H}$ & $0.58^{*}$ & $0.24^{*}$ & & \\
\hline Ethylbenzene & ND & B & 69.36 & $\mathrm{NP}$ & & \\
\hline Xylenes & ND & $\mathrm{S}$ & 125.20 & NP & & \\
\hline Naphthalene & ND & $\mathrm{Ba}$ & 245.50 & 77.20 & & \\
\hline Acenaphthylene & 0.13772 & As & $<5$ & $<5$ & & \\
\hline Acenaphthene & 0.19351 & $\mathrm{Hg}$ & $<0.2$ & $<0.2$ & & \\
\hline Fluorene & 0.19332 & Al & 19285.00 & 17175.00 & & \\
\hline Phenanthrene & 0.37582 & $\mathrm{Fe}$ & 22600.00 & NP & & \\
\hline Anthracene & ND & $\mathrm{Mn}$ & 363.60 & $\mathrm{NP}$ & & \\
\hline Fluoranthene & 0.72512 & $\mathrm{Na}$ & 5386.50 & 129.60 & & \\
\hline Pyrene & 2.48108 & $\mathrm{Cu}$ & 6.39 & NP & & \\
\hline Benzo(a) & 9.3954 & $\mathrm{Zn}$ & 34.30 & NP & & \\
\hline anthracene & & & & & & \\
\hline Chrysene & 1.63009 & $\mathrm{Ni}$ & 3405.00 & 10.27 & & \\
\hline $\begin{array}{l}\text { Benzo(b) } \\
\text { fluoranthene }\end{array}$ & 0.27237 & $\mathrm{Ca}$ & 3883.50 & 114.40 & & \\
\hline $\begin{array}{l}\text { Benzo(k) } \\
\text { fluoranthene }\end{array}$ & 0.45907 & $\mathrm{Cd}$ & $<0.2$ & $<0.2$ & & \\
\hline Benzo(a) pyrene & $\mathrm{ND}$ & $\mathrm{Pb}$ & 215.70 & 40.78 & & \\
\hline $\begin{array}{l}\text { Dibenzo(a,h) } \\
\text { anthracene }\end{array}$ & ND & $\mathrm{Cr}$ & 32.74 & 16.53 & & \\
\hline $\begin{array}{l}\text { Benzo(ghi) } \\
\text { perylene }\end{array}$ & ND & $\mathrm{Mg}$ & 1422.50 & 393.8 & & \\
\hline Total PAHs & 15.5911 & K & 10365.00 & $\mathrm{NP}$ & & \\
\hline & & Mo & 1.61 & 1.37 & & \\
\hline & & $\mathrm{Cl}$ & 1973.00 & 13.48 & & \\
\hline & & $\mathrm{P}$ & 35.26 & $\mathrm{NP}$ & & \\
\hline
\end{tabular}

$\mathrm{NP}$ - analysis not performed ND - not detected * value in $\%$ 
The results in Table 2 were especially important for the substances defined in the residue, because the values should indicate the proportions of the soil and residue masses that should be mixed to compose the material in which part of the experiment would be developed. It was defined that the mixture should be composed of $80 \%$ soil and $20 \%$ residue.

\section{Budding and Plant Growth}

The initial seedling sprouting was normal in all boxes and no seedling has been lost. It was observed that the seedlings of the Salix $\mathrm{x}$ rubens species planted in soil without residue had more shoots and bigger branches as compared with the seedlings planted in the soil with a residue. The color of the leaves of the seedlings planted in soil with residue had more yellow hue in contrast to the green hue of leaves of sprouted plants in soil without residue. The Salix triandra species had sprouting and formation of branches similar in both types of soil, and be identified difference in color of the leaves of the plants which sprouted in the two types of soil. In addition, the color of the leaves of the seedlings planted in soil with residue had a more yellow hue in contrast to the green hue of leaves of the sprouted plants in soil without residue. The Salix triandra species had sprouting and formation of branches similar in both types of soil, and was not identified with difference in color of the leaves of the plants that sprouted in the two types of soil. This fact was verified in the other two periods of sprouting after periods of dormancy of both species.

Considering the period of three years of research and plant development cycles - planting, growth, dormancy and emergence of new leaves - the presentation and discussion of the results were divided into three stages in this study as follows.

\section{_First Stage: Budding and Growth}

It matched the first year of the research, in the period October/year1 to September/year1. There was expectation regarding to the growth of these plants, because the altitude and climate are different in Bom Retiro do Sul and Canoas, municipalities in which, respectively, the plants are traditionally grown and the research was conducted. In Bom Retiro do Sul, the topography is marked by hills with altitudes above 1,000 $\mathrm{m}$, and temperatures vary according to the seasons, between 8 to $19{ }^{\circ} \mathrm{C}$ in spring, 16 to $22^{\circ} \mathrm{C}$ in summer, 9 to $16^{\circ} \mathrm{C}$ in autumn and 6 to $14{ }^{\circ} \mathrm{C}$ in winter. In Canoas, the topography is flat in altitude almost at sea level, and temperatures ranging from 15 to $22^{\circ} \mathrm{C}$ in spring, 19 to $29^{\circ} \mathrm{C}$ in summer, 11 to $22{ }^{\circ} \mathrm{C}$ in autumn and 11 to $19{ }^{\circ} \mathrm{C}$ in the winter. The plants performance both in budding and in growth was normal in Canoas, and the differences between the altitudes and climates constituted no problems. Figure 4 shows the growth of the first buds of the Salix x rubens species.

\section{Figure 4 -Shoots of Salix x rubens}

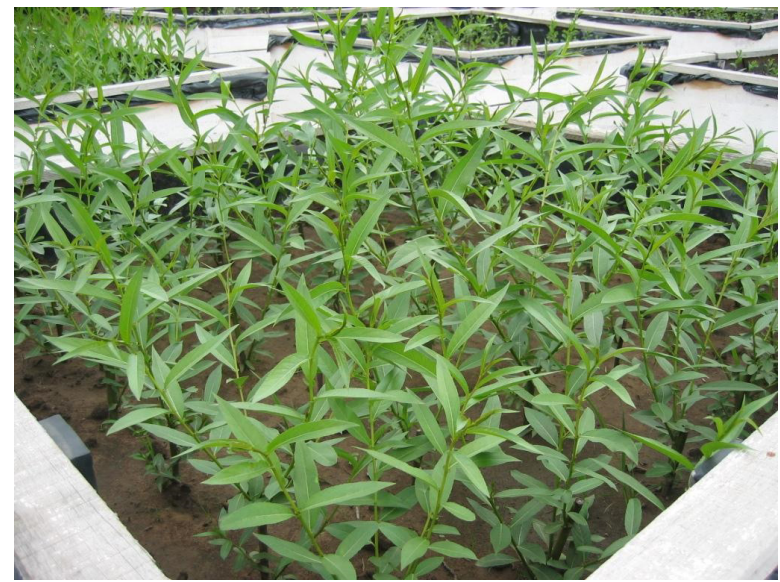

In April/year1, the leaves of the two species began to turn yellow and fall off, indicating the beginning of the first dormant period that lasted until August/ year1. In this period, the first infestation of aphids (Hemiptera) took place. This insect excretes a high-glucose solution that attracts ants and bees to the crops and whose presence indicates the occurrence of the plague (PATRO, 2013). The ants did not attack the leaves. The infestation of aphids, controlled with the solution of water and coconut soap, lasted until the end of plant dormancy period, having been the only problem occurred in the first stage.

\section{- Second Stage: Development of the Plants and Appearance of Fungi}

It corresponded to the second year of the research, in the period October/year2 to September/year2. In October, many new branches have grown in the two species and two soil types, and till February the plant development was normal without problems. In March, there was a new infestation of aphids. In the boxes with soil and residue, in both species, there were unusual episodes so far, like leaves with necrosis and dark spots. The necrosis was also observed at the apex of the branches. Before long, these processes were also installed in growing plants in soil without residue. The leaves analysis having such characteristics indicated the presence of fungi of the Phoma sp., Cercospora sp. and Phyllosticta sp. species causing the Phoma, cercorporiose stain and leaf spot, respectively. According to Saran (2017), the infestation by these species of fungi is favored when the plants grow in damp locations. Figure 5 illustrates a leaf of the Salix x rubens species with stains caused by fungi.

Aphids always began infestations in plants growing in soil without residue, possibly seeking healthier saps. However, in the plants without soil residue, they became infested and the aphids passed to plant growing in soil with residue. With the fungi it occurred otherwise, i.e., their infestation always initiated in plants growing in soil with the residue, and then they passed to plants in soil without residue. 
Figure 5 - Sheet of Salix x rubens with fungi

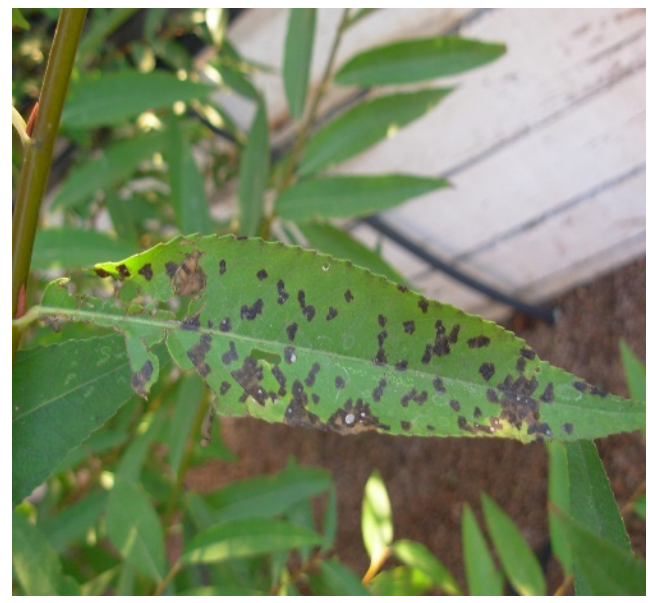

The analysis of necrotic branches indicated the presence of the Botryosphaeria dothidea (Mong.) Ces. \& De Not fungus, which causes the dry disease of branches. The branches had necrosis on the basis that enveloped them completely. In the bark, elongated brown or violet spots appeared. The branches dried from the ends. After opening the wood in longitudinal cut, necrotic and dark spots in depth were verified. After drying the branches, the bark became reddish or brownish with black dots in large quantities, making the fungus fruiting bodies.

The dead branches with cancers were the main source of inoculum. Dark pycnidia containing hyaline conidia and unicellular were also detected in the samples. Conidia produced in pycnidia in the branches are spread during rainy periods (AUER; SANTOS, 2008). As management measures for the control of plant infestation by fungi, the film of polyethylene was withdrawn from the greenhouse cover. The irrigation was reduced from five to three times a week. The branches that had cancers were removed and the wounds were treated with white plastic paint. These measures were sufficient to contain the spread of the problem.

In April, the quantitative control of plant growth was started, a procedure that occurred monthly until the end of the experiment. In June, the two species went into dormancy. Infestations of aphids and fungi were controlled and there were no new problems.

\section{- Third Stage: Monitoring the Growth of the Plants and Aphids and Fungi}

It corresponded to the third year of the survey, in the period October/year3 to September/year3. In November, as in the previous stage, many new shoots sprouted in both species, and in both types of soils. Aphids reappeared, although to a lesser extent, probably due to winter being longer at the end of the previous stage. Since the early sprouting applied to water solution with coconut soap and thus in this stage, the problem with aphids was greatly reduced. However, in January necrosis resurfaced with the first branches darkened and yellowed leaves with dark pigmentation. To contain the spread of fungi, and as a preventive measure, pruning took place in all the plants of all the boxes, which stimulated the plants to issue new shoots and favored ventilation between them, preventing the proliferation of fungi. On the pruned branches, white plastic paint was applied to prevent fungal entry. At this stage, as in earlier stages, it was found that Salix x rubens species was the most susceptible to the attack of fungi causing the leaf spot.

Due to more effective monitoring at this stage, infestation of aphids and fungi was little intense. In addition, as in previous stages, there was no apparent problem for normal growth of the plants of both species, in both types of soil. Not any loss of a plant in the experiment occurred, neither by the occurrence of chemical residue in their tissues, nor by infestation of aphids and fungi. In April, with the fall of all leaves, plants entered dormancy and more problems were not observed with them. Figure 6 and Figure 7 illustrate plants of the Salix $\mathrm{x}$ rubens and Salix triandra species, respectively, at the end of the experiment.

Figure 6 - Salix $x$ rubens

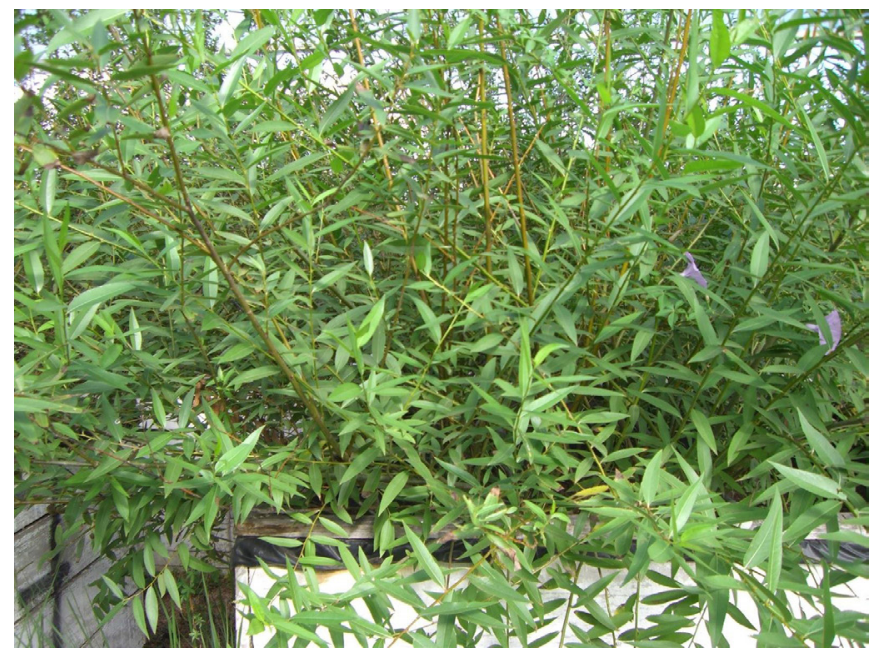

Figure 7 - Salix triandra

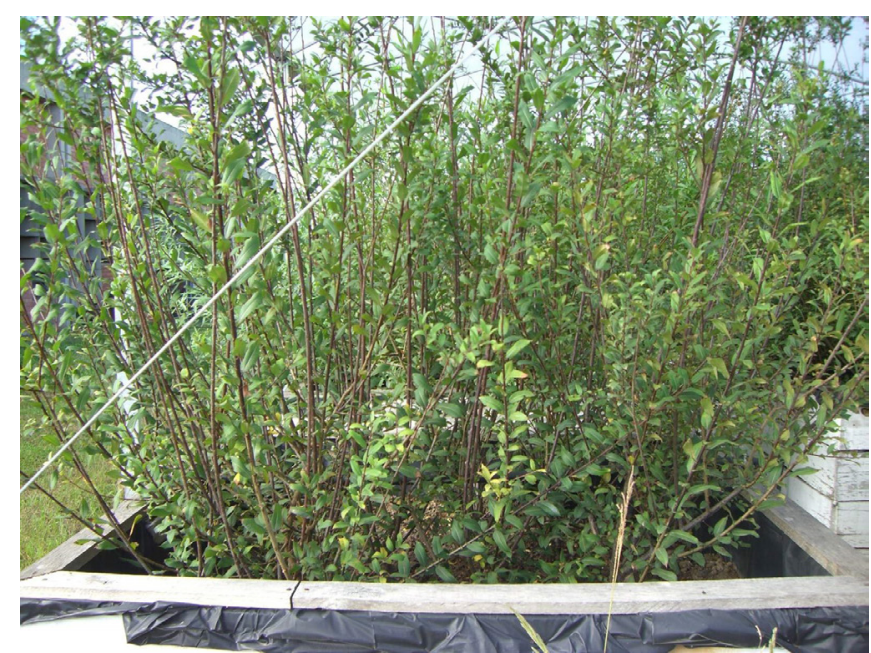




\section{The Development of the Plants Under the Statistical and Visual Assessment}

As previously mentioned, the development of plants was accompanied over the last 18 months of the experiment. In the 36th month, the latest measures of stems and leaves were held and the results are shown in Figures 8, 9 and 10, which illustrate, respectively, the histograms of the diameters of the bases and apexes of the stems, of the heights of the stems and of the dimensions of the leaves. The Q test was used to rule out results and the $t$-student test, considering a $95 \%$ confidence level and the type A uncertainties expanded, associated in statistical evaluation to compare the results. The procedures and main results of this evaluation are found in Cunha et al. (2012). In the figures, the $1 \mathrm{~S}$ indications, for example, represent the plants of box 1 with soil, and the indications $2 S R$ represent box 2 with soil and residue.

Whereas the plants grown in boxes containing only soil were the benchmark of their development, the statistical analysis indicated that Salix $\mathrm{x}$ rubens species of boxes with soil and residue had their development affected by residue chemicals, while the development of Salix triandra species was not affected by the same chemicals. This is also observed in Figures 8, 9 and 10. In Figure 8, both the values of the diameters of the base as those of the apex of the Salix x rubens plants are noticeably greater in the boxes containing only soil. In Salix triandra plants the differences between the values of the boxes with soil and the boxes with soil and residue are not as evident,

Figure 8 - Diameters of the stems

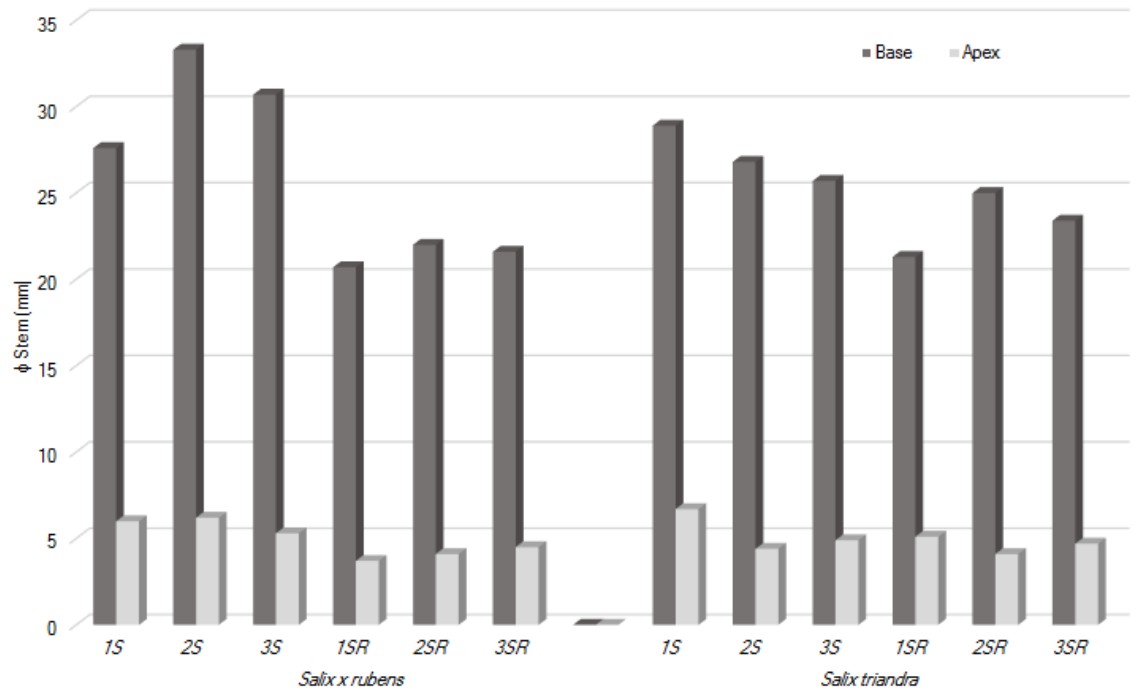

Figure 9 - Height of the stems

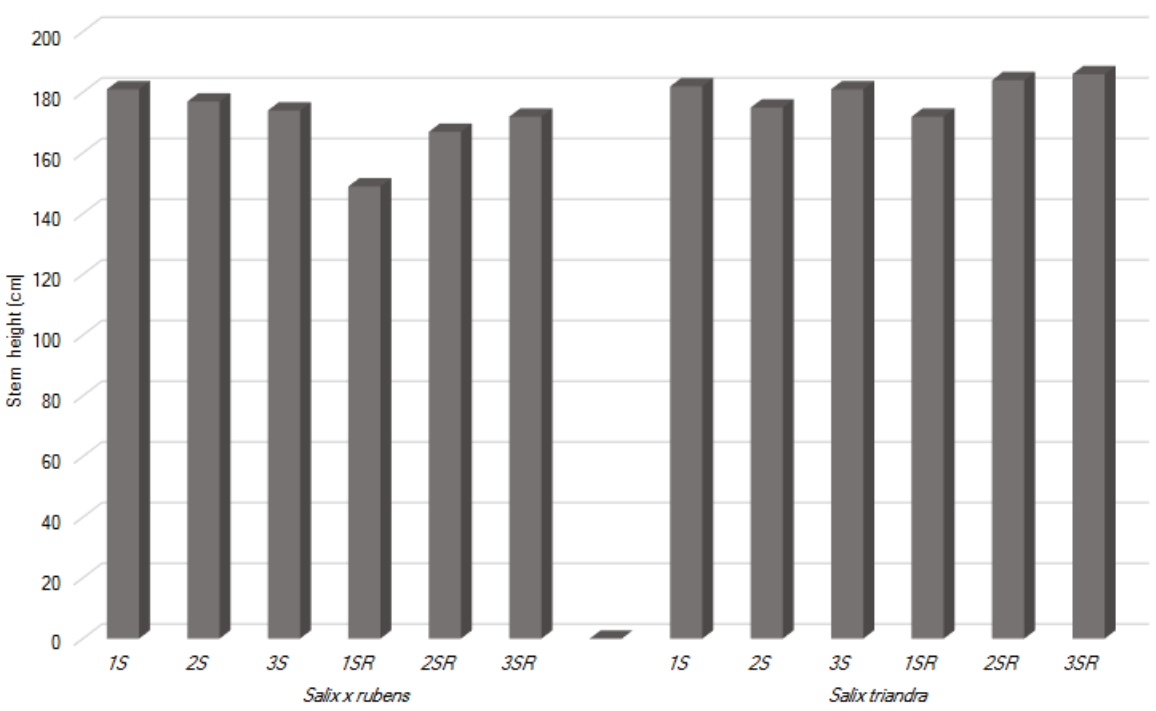


Figure 10 - Dimensions of the leaves

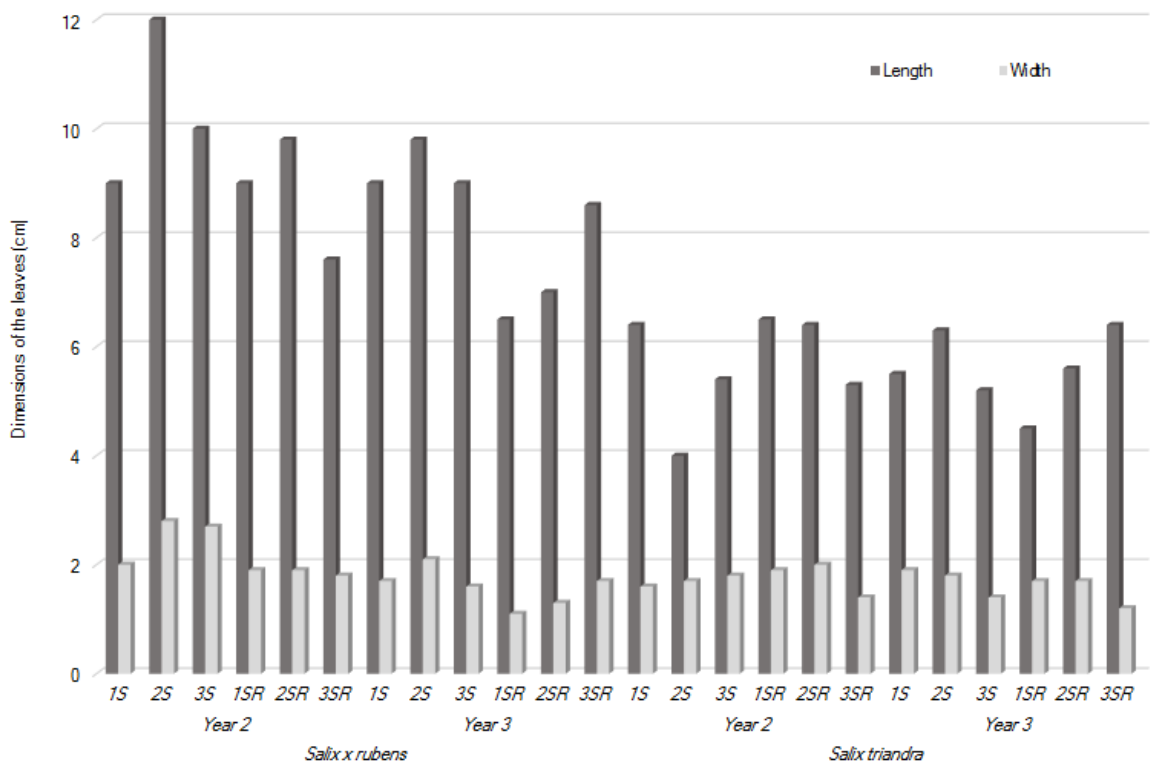

although higher values can be realized for the stem base diameters in plants grown in boxes with soil.

In Figure 9, values that are more homogeneous can be observed for the height of the stems in the Salix x rubens species planted in boxes with soil, and lower values at the height of the stems grown in boxes with soil and residue. However, for the Salix triandra plants trends in the two types of soils are not observed.

As for Figure 10, initially it should be noted that the standard dimensions of the leaves of Salix $\mathrm{x}$ rubens species are larger than those of Salix triandra. The comparison between the values of dimensions of length and width of Salix x rubens leaves shows a tendency to lower values in two years for plants grown in boxes with soil and residue. In Salix triandra plants, clear trends are not observed in both length and width of leaves, in the two years that they were measured. These trends are visible in Figures 11 and 12. Figure 11 illustrates two branches with Salix x rubens leaves, in which the branch 07 is taken from plants grown in box with soil and residue, and the branch 10 plant developed in box with soil. Figure 12 illustrates two branches with Salix triandra leaves, in which the branch 11 is taken from plants grown in box with the soil, and the branch 12 plant grown in box with the soil and residue.

The results presented in Cunha et al. (2012) indicated that the willows of both species were effective for phytoremediation in soil contaminated with hydrocarbon-based, probably due to phytodegradation process. However, plants of Salix triandra species were more resistant to the presence of chemical substances in their tissues, because their development in soil contaminated by substances was very similar to plants grown in soil not contaminated.
Figure 11 - Salix x rubens

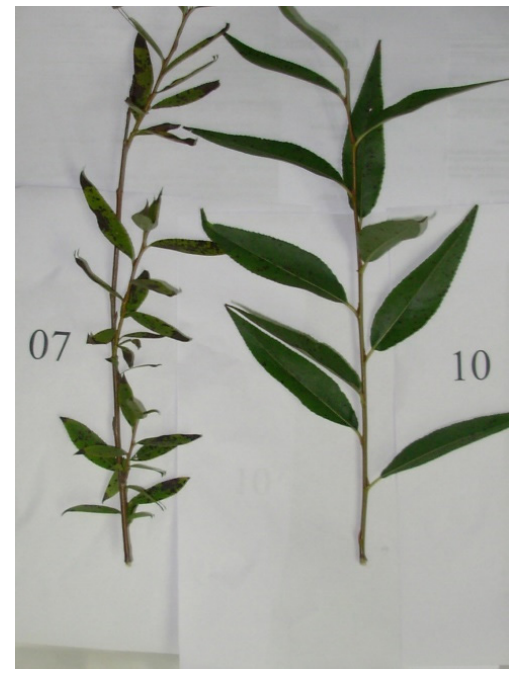

Figure 12 - Salix triandra

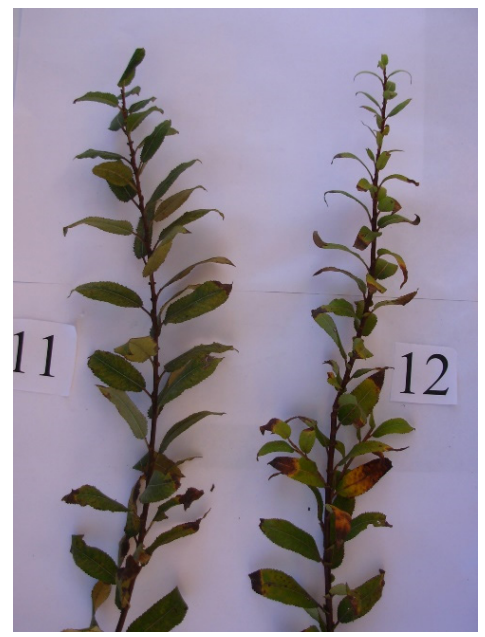




\section{Root Growth}

At the end of the experiment, all the boxes were broken, enabling the visualization of the root network. In 12 boxes, there was good growth and good branching of roots, as shown in Figure 13. Some roots deepened to $80 \mathrm{~cm}$ long, reaching the bottom of the box and being prevented from deepening more, probably due to the plastic bag placed at the base of boxes. Another evidence of good root development was the absence of folding of the root system.

Figure 13 - In situ roots inside the box

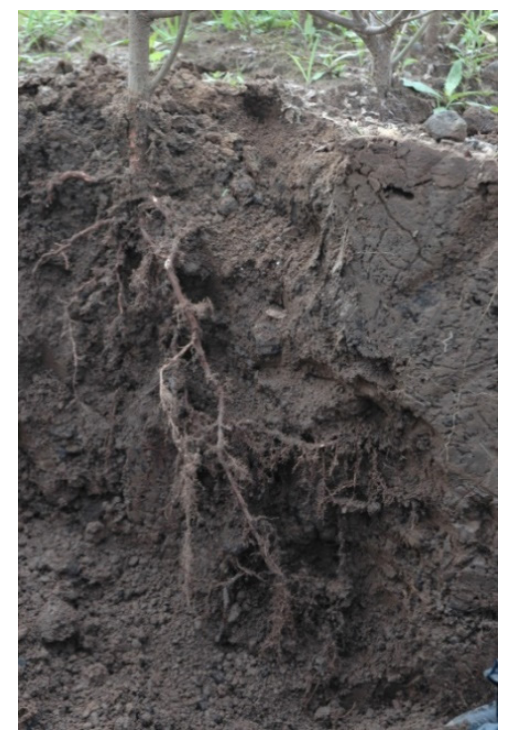

4 Conclusions

Willow seedlings are usually planted in February and March in places where the plant is produced, in the Planalto Serrano Catarinense region, in the State of Santa Catarina. In this study, the planting of seedlings occurred in Canoas, in the State of Rio Grande do Sul, in October. This time difference in planting did not affect the sprouting of seedlings.

In the plant source region, the topography and climate are very different from the region where the experiment was conducted. The two willow species - Salix $\mathrm{x}$ rubens and Salix triandra - had, in addition to sprouting, normal growth over the three years in which the study was conducted, a fact attested by the technicians of the Zandonai, Journet and Thomas Ltda. Company. Topographical and climatic differences did not affect the growth and normal development of plants in Canoas.

To compensate the adverse characteristics of planting season, climate, altitude and soil texture in the place where the experiment was conducted, the correction of $\mathrm{pH}$ and soil nutrients, beyond the strict moisture control, were the measures adopted, which, it is believed, contributed to the plants had normal sprouting and growth.

The seedlings of Salix $\mathrm{x}$ rubens species had more vigorous initial budding and larger branches in boxes containing only the soil. In these boxes, when the leaves grew, it was observed that their color had strong green shades. In the boxes with the mixture of soil and residue IFO 380, the chemical substances in plant tissues affected budding and branching of the plants, and also affected the color of leaves, which have acquired a rather yellowish tone. However, with the seedlings of the Salix triandra species, budding, branching and the green color of the leaves was similar in the two soil types. As the chemical analyzes of plants grown in the boxes with the soil mix, and the residue indicated the presence of the chemicals of the residue, it was concluded that these did not affect the normal development of the Salix triandra species.

Throughout the experiment, infestations of aphids and fungi occurred right after the plant dormancy periods, with the buds and branches already established. Aphids were attacking, initially, in both willow species, the plants growing in the boxes containing only soil and then they passed to the plants in boxes containing soil and residue mixture. This fact indicated that the aphids sought initially healthier plants, with saps free of chemicals from residue. With the fungi, it occurred in the opposite way, i.e., infestation initiated in plants growing in the boxes with the soil and residue, probably more susceptible to the attack because they are less healthy and then they propagated to plants without the chemical residue.

The numbers generated in the growth control of the stems (diameters of apex and base and height) and of the size of leaves of plants of both species had statistical treatments. The results indicated that the diameters of the stems and apices of the Salix x rubens plants, as well as their heights and dimensions of their leaves were lower in boxes containing soil and residue and, hence, the statistical analysis indicated that chemicals IFO 380 residue affected the growth of this species. However, the growth of the controls Salix triandra plants did not show the same trends observed in other species. The statistical analysis of the data of the Salix triandra indicated that the chemical residue did not affect its development.

Considering the results and general and specific assessments of this study, it can be concluded that both kinds of willow had good performance as phytoremediator plants of soil contaminated with hydrocarbon derivatives, of course, with limited dosages for parameters that favor the development of plants. It can be concluded, also, that the Salix triandra willow had the best development of performance when comparing the results of the two species investigated.

Finally, one can also conclude that the methodology developed in this study was effective for the species of plants investigated and the dosage of the residue mixed with soil. The experiment simulated an accidental contamination by spill of the residue. In cases like this, excessive amounts of contaminants may occur and would be concentrated in restricted areas. The soil removal and its ex situ treatment is a recommended procedure, avoiding the infiltration of substances and their propagation into the deeper strata and the groundwater. In this context, the experiment was characterized as an environmentally feasible mitigation tool. 


\section{Acknowledgements}

The authors are grateful to the researchers Filip Tack and Pieter Vervaeke, of Ghent University, for the scientific assessments of the data during the experiment and information about operating procedures with plants; to the researchers Antonia Volpon and Luiz Fernando Martins, Cenpes/Petrobras, for the contributions and scientific assessments during the experiment; to the Petrobras Company, for the project financing (0050.0012424.05.2).

\section{References}

AL-TAISAN WA. Suitability of using Phragmites australis and Tamarix aphylla as vegetation filters in industrial areas. Am J Environ Sci. 2009;6:740-747.

AUER CG, SANTOS AF. Praga Florestal Exótica: Mycosphaerella dearnessii. Colombo: Embrapa Florestas, Comunicado Técnico No. 211; 2008.

BHARGAVA A, CARMONA FF, BHARGAVA M, SRIVASTAVA S. Approaches for enhanced phytoextraction of heavy metals. J. Environ. Manage. 2012;105:103-120.

CARPANEZZI AA, TAVARES FR, SOUZA VA. Produção de Mudas de Vime em sacos Plásticos. Brasília: Embrapa. Ministério da Agricultura, Pecuária e Abastecimento. Comunicado Técnico No. 72; 2002.

CASA J, BOFF MIC, RECH TD, BOFF P. Resistência do Vimeiro, Salix spp. (Salicaceae), à Pragas e Doenças. Ci. Fl. 2007;17(1):1-8.

CUNHA ACB, SABEDOT S, SAMPAIO CH, RAMOS CGR, SILVA AR. Salix rubens and Salix triandra Species as Phytoremediators of Soil Contaminated with PetroleumDerived Hydrocarbons. Water, Air, Soil Pollut. 2012;223(8): 4723-4731.

CUNNINGHAM SD, ANDERSON TA, SCHWAB AP, HSU FC. Phytoremediation of soils contaminated with organic pollutants. Adv. Agron. 1996;56:55-114.

DICKINSON NM, PUNSHON T, HODKINSON RB, LEPP NW. Metal tolerance and accumulation in willows. In: ARONSSON P, PERTTU K, Editors. Willow vegetation filters for municipal waste-waters and sludges: a biological purification system. Sveriges Lantbruksuniversiteit, Uppsala; 1994.

ERICKSSON J, LEDIN S. Changes in phytoavailability and concentration on cadmium on soil following long-term Salix cropping-water. Water, Air, Soil Pollut. 1999;14:171-184.

GOOR F, DAVYDCHUK V, LEDENT JF. Assessment of the potential of willow SRC plants for energy production in areas contaminated by radionuclide deposits: methodology and perspectives. Biomass Bioenergy. 2001;21:225-235.
KLANG-WESTIN E, PERTTU K. Effects of nutrient supply and soil cadmium concentration on cadmium removal by willow. Biomass Bioenergy. 2002;23:415-426.

LEMOS RD, SANTOS RD. Manual de descrição e coleta de solos no campo. 2 ${ }^{\mathrm{a}}$ ed. Campinas: Sociedade Brasileira de Ciência do Solo/Embrapa-SNLCS; 1982.

MCCUTCHEON SC, SCHNOOR JL. Phytoremediation: Transformation and Control of Contaminants. Hoboken: Wiley Interscience; 2003.

MEERS E, VERVAEKE P, TACK FMG, LUST N, VERLOO M, LESAGE E. Field trial experiment: Phytoremediation with Salix sp. On a dredged sediment disposal site in Flanders, Belgium. Remed J. 2003;13:87-97.

MEIKLE RD. Willows and poplars of Great Britain and Ireland. London: Botanical Society of the British Trees; 1984.

MERTENS J, LUYSSAERT S, VERBEEREN S, VERVAEKE $P$, LUST N. Cd and Zn concentration in small mammals and willow leaves on disposal facilities for dredged material. Environ. Pollut. 2001;115(1):17-22.

MOURA VPG. Introdução de Novas Espécies de Salix (Salicaceae) no Planalto Sul de Santa Catarina, Brasil. Brasília: Embrapa. Ministério da Agricultura, Pecuária e Abastecimento. Comunicado Técnico No. 71; 2001.

MUDGAL V, MADAAN N, MUDGAL A. Heavy metals in plants: phytoremediation. Plants used to remediate heavy metal pollution. ABJNA. 2010;1(1):40-46.

MULLIGAN CN, YONG RN, GIBBS BF. Remediation technologies for metal contaminated soils and groundwater: An evaluation. Eng Geol. 2001;60:193-207.

PATRO R. Pulgão. Jardineiro.Net; 2013 Sep 01 [cited 2017 nov 15]. Availabre from http:/www.jardineiro.net/pragas/ pulgao.html.

SARAN PE. Manual de identificação das doenças da soja; [cited 2017 nov 15] Available from: https://www.fmcagricola. com.br/portal/manuais/doencas_soja/files/assets/common/ downloads/publication.pdf.

VANDECASTEELE B, DE VOS B, TACK FMG. Cadmium and Zinc uptake by volunteer willow species and elder rooting in polluted sediment disposal sites. Sci Total Environ. 2002;299:191-205.

VERMEIRE MB. Everything You Need to Know About Marine Fuels. Ghent: Chevron Global Marine Products; 2012.

VERVAEKE P, LUYSSAEET S, MERTENS E, TACK FMG, LUST N. Phytoremediation prospects of willow stands on contaminated sediment: a field trial. Environ. Pollut. 2003;126:275-282. 
VERVAEKE P, LUYSSAERT S, MERTENS J, DE VOS B, SPELEERS L, LUST N. Dredged sediment as a substrate for biomass production of willow trees established using the SALIMAT technique. Biomass Bioenergy. 2001;21:8190.

\section{Contribuição dos autores}

Sydney Sabedot

Contribuições substanciais para a concepção do trabalho; aquisição; análise ou interpretação de dados; redigiu o trabalho ou realizou uma revisão substancial.

\section{Sérgio Augusto de Loreto Bordignon}

Contribuiç̃es substanciais para a concepção do trabalho; aquisição; análise ou interpretação de dados; redigiu o trabalho ou realizou uma revisão substancial.

Ana Cristina Borda da Cunha

Contribuições substanciais para a concepção do trabalho; aquisição; análise ou interpretação de dados; redigiu o trabalho ou realizou uma revisão substancial. 